Мисия И ЦЕА

Идеята за това печатно издание възниква след утвърждаването на Професионалната организация на болничните фармацевти (ПОБФБ) у нас, като сдружение с нестопанска цел защитаващо интересите на тази група медицински специалисти. То е създадено за да запознава фармацевтичната общност с проблематиката и спецификата на работата на болничния фармацевт.

Целта на списанието "Годишник по болнична фармация" е не само да осигури достъп на всички заинтересувани до информация за фармацевтичната практика и фармакотерапията в болнични условия, но и да предложи редовно излизащо авторитетно издание, представящо обзори и стойностни научни изследвания.

В изданието се публикуват исторически, теоретични и практически материали, отнасящи се до болничната фармация в България, Европа и по света. Във всеки брой редакционната колегия запознава широката читателска аудитория и с постиженията на чуждестранни специалисти, посредством публикуване на преводни статии от Европейското списание по болнична фармация (European journal of hospital pharmacy).

Мисията на списанието е да обогати познанията на болничните фармацевти и други заинтересовани лица и да спомогне за подобряване на тяхната информираност.

Списанието е с научен характер и се издава в един брой годишно. Изискванията към авторите са стандартните за българската научна медицинска периодика. Публикуването на статии е безплатно. Списанието е включено с идентификационен код (ISSN) в международната система за регистрация на периодичните издания.

Редакционната колегия на сп. "Годишник по болнична фармация" искрено се надява да предлага фармацевтично списание, което да съответства на високите съвременни изисквания и допринася за научното познание и удовлетворение на всички читатели!

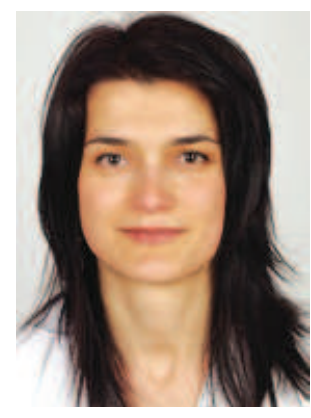

Уважаеми колеги,

От появата си преди девет години досега нашето сдружение извървя дълъг и труден път на утвърждаване и отстояване на позиции както в страната, така и на европейско ниво.Издигането на авторитета на професията „Болничен фармацевт“ пред държавни институции, различни организации и фирми работещи в областта на здравеопазването, е приоритет още от самото начало. Всички ние работим в обстановка на постоянни предизвикателства, които могат да бъдат решени успешно само с висок професионализъм, много труд, находчивост и непрекъснато усъвършенстване.

Държите в ръцете си първия брой на „Годишник по болнична фармация“ - печатното издание на Професионалната Организация на Болничните Фармацевти в България. В него ще намерите много интересни статии както от български водещи специалисти, така и чуждестранни публикации в областта на болничната фармация, предоставени ни от издателите на ЕЈНР. Ние, от УС на ПОБФ, се надяваме „Годишник по болнична фармация“ да стане традиция, както конференциите, които организираме всяка година. Надяваме се, всеки от Вас да намери нещо в него за себе си, което да му помогне да бъде още по-полезен за другите здравни специалисти и, най-вече, за пациентите. 


\section{AIM AND MISSION}

The idea for this publication arises after the establishment of the Professional organization of hospital pharmacists (POBFB) in our country, a non-profit organization protecting the interests of this group of medical professionals. It was created to introduce the pharmaceutical community with issues and specifics of the work of hospital pharmacist.

The aim of the journal "Annual for hospital pharmacy" is not only to provide access to all relevant information for the pharmaceutical practice and pharmacotherapy in the hospital, but also to offer regularly published authoritative publication presenting overviews and valuable research.

The journal publish historical, theoretical and practical materials related to hospital pharmacy in Bulgaria, Europe and worldwide. In each issue Editorial board met wider readership and achievements of foreign specialists through the publication of translated articles from European Journal of Hospital Pharmacy.

The mission of the journal is to enrich the knowledge of hospital pharmacists and other stakeholders to help improve their awareness.

The magazine has a scientific nature and is published in one issue per year. Requirements to authors meet the standard for Bulgarian scientific medical periodicals. The publication of an articles is free of charge. The journal is included with an identification code (ISSN) in the international system for registration of periodic publications.

The Editorial board of the journal "Annual for hospital pharmacy" sincerely hopes to offer pharmaceutical publication, which correspond to the highest modern requirements and contribute to scientific knowledge and satisfaction of all readers! 